\title{
がん専門病院の緩和ケア病棟で行われている デスカンファレンスの内容分析
}

\author{
角甲 純 ${ }^{1)}$, 大園 康文 ${ }^{2)}$, 小林 成光 ${ }^{1)}$, 關本 翌子1) \\ 1）国立がん研究センター東病院 看護部, 2) 防衛医科大学校 医学教育部 看護学科 地域看護学講座 \\ 【目的】デスカンファレンスで話し合われた内容を明らかにする.【方法】2012 年 5 月〜2014 年 11 月までの期間 \\ に, 国立がん研究センタ一東病院の緩和ケア病棟で行われたデスカンファレンス 60 件について, 診療録およびデス \\ カンファレンス実施時の記録用紙を後ろ向きに調査し, 内容分析を行った.【結果】期間中に行われたデスカンファレ \\ ンスから，170 単位のデータを抽出した．最終的に 5 つのカテゴリーに分類し，[ケア対象としての家族を支える] \\ [患者の思いを汲み取り大切にする] [症状を緩和し苦痛を取り除く] [医療者間における連携の大切さを実感する] [患 \\ 者との関わりに苦慮する]とした.【結論】デスカンファレンスは, さまざまな視点と方向から支援を振り返る有用な \\ 機会であることが示唆された. \\ Palliat Care Res 2018; 13(1): 115-20
}

Key words: 癌看護, ホスピス, 看護師, 緩和ケア, ターミナルケア

\section{緒 言}

終末期がん患者への支援を提供する場面では，患者 の死や死の過程に対する支援や，患者・家族の苦悩を 見続けることで, 何もできなかったという無力感や, 提供した支援方法で本当によかったのだろうかという 倫理的な葛藤やストレスを経験することが多い．その ような中で，よりよい患者・家族支援を実現したいと いう思いから，終末期に提供された支援を振り返る， デスカンファレンスを実施している施設がある。

デスカンファレンスは「死亡事例の終末期ケアに関 する検討会」と定義1)されており, 開催する意義につい ては「ケアを評価してこれからのケアにいかすことが できる」「患者・家族への理解が深まる」「医師と看護師 の考え方のずれが明らかになって互いの理解が深ま る」と言われている2).

実際のデスカンファレンスで話し合われている内容 については, 症例報告単位では散見されるが3,4), 話し 合いの内容を集積した報告はない。デスカンファレン スで話し合われている内容を集積することで，終末期

受付日 2017 年 10 月 3 日 / 改訂日 2018 年 2 月 12 日 / 受理日 2018 年 2 月 15 日

Corresponding Author：角甲 純 国立がん研究センター東病院 看護部 干 277-8577 千葉県柏市柏の葉 6-5-1 TEL 04-7133-1111 FAX 04-7131-9960 E-mail: jkako-tky@umin.ac.jp
がん患者とその家族への支援について, 看護師が大切 にしている支援の視点や，悩みながら行っていた支援 の傾向が明らかとなり，今後の終末期がん患者とその 家族支援に対する有用な情報が得られると考える。そ こで, 本研究では, デスカンファレンスで話し合われ た内容を集積して分析することで，デスカンファレン スで話し合われている視点とその傾向を明らかにする ことを目的とする

\section{方 法}

対象

2012 年 5 月〜 2014 年 11 月までの期間に，国立がん 研究センター東病院の緩和ケア病棟 (以下, 当院の PCU) で行われた，デスカンファレンス 60 件を対象と した。

デスカンファレンスの開催について

デスカンファレンスは, 定例カンファレンスの時間 (13 時 30 分〜14 時)を利用して, 緩和ケア病棟で開催 する。参加者数はおよそ 7 人程度で, 看護師, 医師, 薬剤師などである ${ }^{5,6)}$. 進行と書記は看護師が担当し, 書記はデスカンファレンスで話し合われた内容を記録 シート(以下，デスカンファレンスシート)に記載す る。デスカンファレンスシートは, 開催日時, 開催時 間, 参加者, 患者背景, キーパーソン, 入院後の経過 を記載する欄および，デスカンファレンスで話し合わ れた内容を記載するスペース（A4 用紙 $1 / 4$ 程度の余白） を設けている。デスカンファレンスに当日参加できな 
かったスタッフも内容を共有できるよう, デスカン ファレンスシートは病棟の看護ステーション内に揭示 している.

\section{調查手順}

入院診療録およびデスカンファレンスシートを後ろ 向きに調査し, 内容分析を行った。本研究は, 国立が ん研究センター研究倫理審査委員会の承認を得て行っ た(承認番号 2013-285). 本研究の目的, 対象, 方法, 個人情報の取り扱い方法, 問い合わせ先などを明記し た文書を国立がん研究センター東病院のホームページ に揭載し，対象者に対する情報提供とデー夕の研究へ の利用を拒否する場合の対応を行った。

\section{分析方法}

まず，デスカンファレンスを実施した患者の背景情 報について調べ，記述統計量を算出した。

次に, デスカンファレンスシートの内容について, クリッペンドルフの内容分析7) 参考にして, 記述内 容をテキストデータ化し内容分析を行った。対象と なった記述内容は，1つの意味内容を 1 単位のコード (本文中では,「」で記載)として抽出した，1件のデ スカンファレンスシートの中で, 異なる意味内容が含 まれる場合は複数のコードとして抽出した。抽出され たコードは，意味内容と類似性を基にユニットをまと めサブカテゴリーを作成した。ささらに，サブカテゴ リー(本文中では,〈〉で記載) は類似するデスカン ファレンスでの話し合いの意味内容で分類し，カテゴ リー(本文中では，［］で記載)を作成した。分析は 2 名の研究者が独立して行い, 緩和ケア領域における研 究経験を豊富に有する緩和ケア専門家と, 質的研究の 経験があり，緩和ケア領域における臨床経験を豊富に 有する緩和ケア専門家のスーパービジョンを受けた。

\section{結 果}

患者背景を表 1 に示す。対象者の過半数は男性で, がん原発部位は肝胆膵, 頭頸部, 胃の順に多かった。

60 件のデスカンファレンスシートから意味内容を 1 単位ずつ抽出すると, 170 単位のデー夕となった。こ れらのデータについて類似性を基にして帰納的に分類 した結果, 23 のサブカテゴリーに分類され, 最終的に 5つのカテゴリーに分類された. 5つのカテゴリーの名 称は，［ケア対象としての家族を支える][患者の思い を汲み取り大切にする][症状を緩和し苦痛を取り除 く][医療者間における連携の大切さを実感する][患者 との関わりに苦慮する]とした。 カテゴリーは表にま とめ, 含まれるサブカテゴリーについては, 代表的な 回答としてデー夕を入れた(表 2). 最も多くのコード を含むカテゴリーは[ケア対象としての家族を支える

\section{表 1 対象者背景 $(\mathrm{N}=60)$}

\begin{tabular}{lc}
\hline & $\begin{array}{c}\mathrm{n}(\%) \text { または mean } \pm \mathrm{SD}, \\
\text { median[range }]\end{array}$ \\
\hline 性別 & \\
男性 & $41(68.3)$ \\
女性 & $19(31.7)$ \\
年齢 & $62.5 \pm 13.4$ \\
婚姻状況 & \\
未婚 & $5(8.3)$ \\
既婚 & $48(80.0)$ \\
別居もしくは離婚 & $1(1.7)$ \\
死別 & $6(10.0)$ \\
がん原発部位 & \\
肝胆膵 & $15(25.0)$ \\
頭頸 & $14(23.3)$ \\
胃 & $9(15.0)$ \\
肺 & $7(11.7)$ \\
大腸 & $7(11.7)$ \\
乳 & $2(3.3)$ \\
子宮・卵巣 & $2(3.3)$ \\
その他 & $4(6.7)$ \\
がん罹患期間 & $35.5 \pm 52.0$ \\
入院形態 & \\
入院 & $26(43.3)$ \\
転棟 & $34(56.7)$ \\
緩和ケア病棟入院日数 & $23.5[4-167]$ \\
\hline & \\
\hline &
\end{tabular}

$(\mathrm{n}=51,30 \%)$ ]であり, [患者の思いを汲みとり大切に する $(\mathrm{n}=42,24.7 \%)$ ] [症状を緩和し苦痛を取り除く $(n=34,20 \%)]$ と続いた，最も少ないコードを含むカテ ゴリーは[患者との関わりに苦慮する $(\mathrm{n}=21,12.4 \%)]$ であった。

\section{考 察}

本研究では, 当院のPCUで開催されたデスカンファ レンスが，どのような視点で話し合われているかを明 らかにした。

詳細に見ると，［ケア対象としての家族を支える］は 最も多くのコード数を含むカテゴリーであり，ケア対 象として家族を捉えることの重要性が語られていた。 家族への支援は，患者支援に比べると時間的制約があ り，臨床では支援に難渋することが多い．時間的制約 がある中で家族が医療者から必要な支援を受けるため には，医療者が家族のニーズを素早く捉える必要があ る。本研究結果で示された，家族の意向に沿った支援 を考えること, 家族の負担感や疲労感に注目するこ と，家族背景を理解し支援にあたることなどは，家族 のニーズを捉えるための重要な視点である.

2 番目に多くのコード数を含むカテゴリーは[患者 の思いを汲み取り大切にするであり，患者の意向を 
表 2 デスカンファレンスシートの内容分析 $(\mathrm{N}=170)$

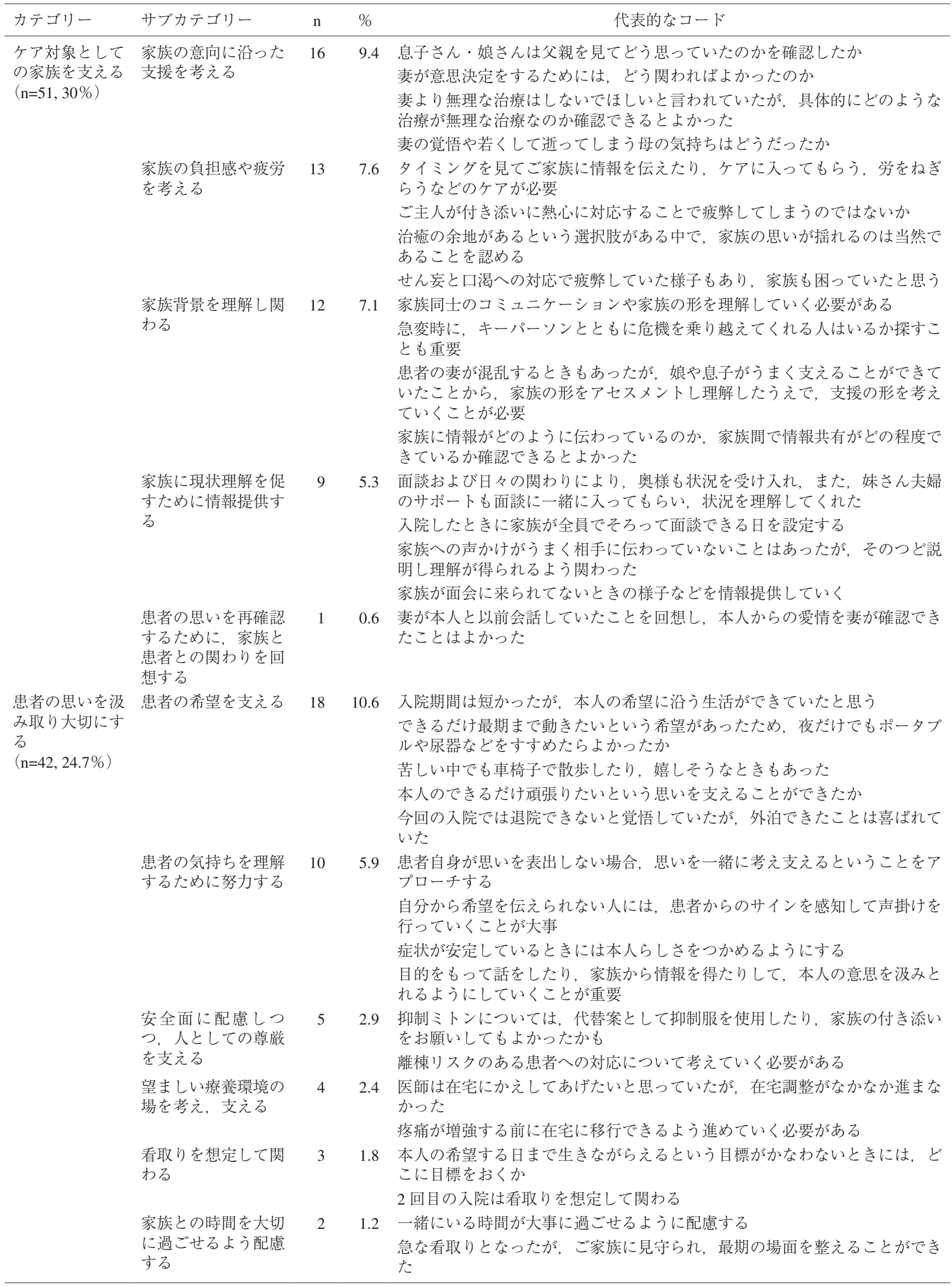


表 2 (つづき)

\begin{tabular}{|c|c|c|c|c|}
\hline カテゴリー & サブカテゴリー & $\mathrm{n}$ & $\%$ & 代表的なコード \\
\hline \multirow{13}{*}{$\begin{array}{l}\text { 症状を緩和し苦 } \\
\text { 痛を取り除く } \\
(\mathrm{n}=34,20 \%)\end{array}$} & \multirow{5}{*}{$\begin{array}{l}\text { 緩和しない症状の難 } \\
\text { しさを感じる }\end{array}$} & \multirow[t]{5}{*}{13} & \multirow[t]{5}{*}{7.6} & 痛みのコントロールが難しいことからゴール設定が難しくなっていた \\
\hline & & & & $\begin{array}{l}\text { 予防的レスキューやコントミンを使用してスタッフ数名でケアを実施してい } \\
\text { たが, 疼痛コントロール困難であり, 必要最低限のケア以外は本人は希望さ } \\
\text { れず, またスタッ側も躊踔していたところもあた }\end{array}$ \\
\hline & & & & 意識もはっきりとしない中で, 何がどこまで辛いのかわかりづらかった \\
\hline & & & & 呼吸状態の悪化に対する薬物療法がうまくいっていなかった \\
\hline & & & & せん妄のコントロールがうまくつけられず, 夜間も不眠が続いていた \\
\hline & \multirow{4}{*}{$\begin{array}{l}\text { 患者家族の希望に } \\
\text { 沿った治療であった } \\
\text { か考える }\end{array}$} & \multirow[t]{4}{*}{9} & \multirow[t]{4}{*}{5.3} & $\begin{array}{l}\text { 本人は眠気に対して OK と話していたが，実母は命を縮めても苦痛をとって } \\
\text { ほしいと話していた }\end{array}$ \\
\hline & & & & $\begin{array}{l}\text { せん妄だからといってすぐに薬を使わずに, 本人の思いをもう少し受け止め } \\
\text { てもよかったかもしれない }\end{array}$ \\
\hline & & & & $\begin{array}{l}\text { 本人の睡眠剤を早く使ってほしいという思いと, 家族の思いにギャップが } \\
\text { あった }\end{array}$ \\
\hline & & & & $\begin{array}{l}\text { 患者の苦悩と患者の安全を守る目的で間歇的鎮静を行ったが, 本人の意思は } \\
\text { どうであったか }\end{array}$ \\
\hline & $\begin{array}{l}\text { 症状に合わせた治療 } \\
\text { を選択する }\end{array}$ & 5 & 2.9 & $\begin{array}{l}\text { せん妄に対して内服から注射にきりかえたことがよかった } \\
\text { 肺炎による症状を緩和することを目的に治療を行いたいと医師は考えていた }\end{array}$ \\
\hline & $\begin{array}{l}\text { 治療による効果と悪 } \\
\text { 影響のバランスを考 } \\
\text { 慮する }\end{array}$ & 4 & 2.4 & $\begin{array}{l}\text { アカシジアの緩和とせん妄の緩和, どちらを優先すべきかで悩んでいた } \\
\text { 浮腫に対してステロイドを使いたかったが, せん妄があったために躊躇され } \\
\text { た }\end{array}$ \\
\hline & \multirow[t]{2}{*}{$\begin{array}{l}\text { 苦痛を緩和するため } \\
\text { に要因を探索する }\end{array}$} & \multirow[t]{2}{*}{3} & \multirow[t]{2}{*}{1.8} & $\begin{array}{l}\text { コントロール感の喪失を体験している患者では, 小さなことでも何か他者に } \\
\text { 与えることができるという達成感が苦痛緩和に有用かもしれない }\end{array}$ \\
\hline & & & & せん妄の原因は不明であったが，採血結果で脱水だということがわかった \\
\hline \multirow{6}{*}{$\begin{array}{l}\text { 医療者間に抒け } \\
\text { る連携の大切さ } \\
\text { を実感する } \\
(\mathrm{n}=22,12.9 \%)\end{array}$} & \multirow{4}{*}{$\begin{array}{l}\text { 医療者間で情報共有 } \\
\text { 文, 対応策を検討す } \\
\text { る }\end{array}$} & \multirow[t]{4}{*}{15} & \multirow[t]{4}{*}{8.8} & $\begin{array}{l}\text { 患者家族関係は，それぞれケースによって異なるため，残された時間をどの } \\
\text { ように過ごしたいのかを，早めに情報共有する }\end{array}$ \\
\hline & & & & $\begin{array}{l}\text { 本人の中で清潔ケアがどのような意味をもつのか, 日々のカンファレンスで } \\
\text { チーム内で話し合いが持てたことはよかった }\end{array}$ \\
\hline & & & & 治療方針について，医師・看護師ともに悩みながら関わっていた \\
\hline & & & & $\begin{array}{l}\text { 本人が意思決定を行うのは困難であったために, 妻の代理決定を行ったが, } \\
\text { そのことについて何度もカンフレンスに取り上げて倫理的にどうかと話 } \\
\text { し合いができていた }\end{array}$ \\
\hline & \multirow[t]{2}{*}{$\begin{array}{l}\text { それぞれの職種の強 } \\
\text { みを活かし支援する }\end{array}$} & \multirow[t]{2}{*}{7} & \multirow[t]{2}{*}{4.1} & $\begin{array}{l}\text { 対応に困る場面はたびたびあり，医師と看護師間での話し合いを密にし，医 } \\
\text { 師からも一声かけてもううとまた違った反応があたかもしれな }\end{array}$ \\
\hline & & & & $\begin{array}{l}\text { バッドニュースの受け入れ・退院調整についてみんなが気をかけ, タイム } \\
\text { リーに対応できた }\end{array}$ \\
\hline \multirow[t]{7}{*}{$\begin{array}{l}\text { 患者との関わり } \\
\text { に苦慮する } \\
(\mathrm{n}=21,12.4 \%)\end{array}$} & \multirow[t]{2}{*}{$\begin{array}{l}\text { 関わる時間が短く, } \\
\text { 難しさを感じる }\end{array}$} & \multirow[t]{2}{*}{7} & \multirow[t]{2}{*}{4.1} & $\begin{array}{l}\text { 年齢も若く急激な病状進行であり, 難しかった } \\
\text { 予後予測が難しく, 症状の進行が早かっため, 退院調整がうまくいかな } \\
\text { かった }\end{array}$ \\
\hline & & & & 関わりが短く, 信頼関係を築けた実感がない \\
\hline & \multirow[t]{2}{*}{$\begin{array}{l}\text { 気持ちを聞くことが } \\
\text { 難しいと感じる }\end{array}$} & \multirow[t]{2}{*}{5} & \multirow[t]{2}{*}{2.9} & $\begin{array}{l}\text { コミュニケーションが図れず，本人の思いなどがまったくわからないことが } \\
\text { 多々あった }\end{array}$ \\
\hline & & & & $\begin{array}{l}\text { 患者の常識がこちらの常識とはかけ離れていることで, 普通に接することで } \\
\text { 辛い気持ちになるこが多々あた }\end{array}$ \\
\hline & $\begin{array}{l}\text { 理解度に応じた関わ } \\
\text { りの難しさを感じる }\end{array}$ & 5 & 2.9 & $\begin{array}{l}\text { 本人の病状の認識と理解にギャップがあった } \\
\text { 認知機能障害に伴う行動があり, 対応困難であった }\end{array}$ \\
\hline & $\begin{array}{l}\text { もっとできたことが } \\
\text { あったのかと後悔す } \\
\text { る }\end{array}$ & 3 & 1.8 & $\begin{array}{l}\text { 母親としての役割を話しておくべきだった } \\
\text { 調子が悪くなる前の } 1 \text { 週間くらいは症状が緩和されているときがあった。 そ } \\
\text { の期間に何かできたことがあったかもしれない }\end{array}$ \\
\hline & $\begin{array}{l}\text { 怒りをぶつけられる } \\
\text { ことに辛さを感じる }\end{array}$ & 1 & 0.6 & $\begin{array}{l}\text { 長期の入院であり，怒りをぶつけられることで, こちらも接することが辛 } \\
\text { かった }\end{array}$ \\
\hline
\end{tabular}

尊重することの重要性が語られていた，とくに，〈患者 の希望を支える〉というサブカテゴリーは，患者が辛 い体験をしている中でも，患者の思いを達成できるよ うな支援が語られていた。 また，このサブカテゴリー
は，すべてのサブカテゴリーの中で最も多くのコード 数を含むことから，医療者が大切にしている支援の視 点であると推察される。

次に多くのコード数を含むカテゴリーは[症状を緩 
和し苦痛を取り除く】であり, 症状緩和の困難さが語 られていた。進行がん患者はさまざまな症状を体験 し ${ }^{8)}$ ，それらの症状は看取りの時期が近づくにつれ， 頻度も強度も増すことが報告されている からも，終末期がん患者の症状緩和は困難である可能 性が高いことを想定し，事前に患者がどのような支援 を受けたいと考えているかを尋ね，患者・家族と医療 者間で共有することが重要である.

[医療者間における連携の大切さを実践する]では, 終末期の患者・家族を支援する医療者が, 情報の共有 を通して，同じ方向を向いて各職種の役割を発揮しよ うと努めることの重要性が語られていた。患者・家族 の支援については，各職種は各々の役割行動をとって おり, また, 相手の職種がとる行動様式を期待(役割期 待) している ${ }^{10)}$ 。この役割行動と役割期待の齟踾から, 目指す支援の方向性にずれが生じると，患者と家族が 必要とする支援を受けられない可能性がある。本研究 結果で語られている，医療者間に拈ける情報共有は， 医療者間の連携を強化するために，重要な視点である。

最も少ないコード数を含むカテゴリーは[患者との 関わりに苦慮する]であり，支援に対する不全感につ いて語られていた。精神的疲労の蓄積は, 医師 ${ }^{11 \sim 13)}$. 看護師 ${ }^{14)}$ ともにバーンアウトに繋がる可能性があり, そのサポートの重要性が指摘されている ${ }^{15)}$. そのた め，支援に苦慮するケースではとくに，日々のカン ファレンスにて，医療者間で肯定的な評価を行えるよ うな環境や，話しやすい雲囲気つくりをすることが大 切だと考える。

本研究の強みは, 1 年半の期間に連続して開催され たデスカンファレンスの内容を分析したことである. 一方で，単施設での報告であるため，一般化するには 限界がある。

\section{結 論}

デスカンファレンスにより話し合われている内容 は，5つに大別することができた。 これにより，デス カンファレンスを行うことで，終末期がん患者とその 家族にとって大切なケアのあり方を，さまざまな視点 と方向から振り返る有用な機会になることが示唆さ れた。

著者の申告すべき利益相反なし

角甲は研究の構想およびデザイン, 研究データの収 集, 分析, 研究データの解釈, 原稿の起草に貢献した. 大園, 小林は研究の構想およびデザイン, 研究データ
の収集, 分析, 研究データの解釈, 原稿の重要な知的 内容に関わる批判的な推敲に貢献した。關本は, 研究 データの解釈, 原稿の重要な知的内容に関わる批判的 な推敲に貢献した。また，すべての著者は投稿論文な らびに出版原稿の最終承認, および研究の説明責任に 同意した。

\section{文 献}

1）安藤悦子, 吉田美也子, 岩田千波, 他. ホスピス・緩和 ケア病棟におけるデスカンファレンスの機能一ホスピ ス・緩和ケア病棟師長の視点より一. 死の臨床 2010; 33: 126-32.

2）広瀬寛子. デスカンファレンスとは何か一意義と実際. 看護技術 2010; 56: 64-7.

3）和泉典子，秋山美紀，奥山慎一郎，他．地域に扮ける多 施設・多職種デスカンファレンス参加者の体験に関す る探索的研究. Palliative Care Research 2012; 7: 354-62.

4）天野晃滋，馬場美華，杉浦孝司，他，緩和ケア病棟での デスカンファレンスの意義の検討一肝がん患者を裖瘡 に起因する壊死性筋膜炎で亡くした経験を通して一.

Palliative Care Research 2012; 7: 568-74.

5）關本翌子。国立がんセンター東病院緩和ケア病棟にお けるデスカンファレンスの実践. 看護技術 2010; 56: 593-6.

6）角甲 純, 小林成光, 關本翌子. がん専門病院の緩和ケ ア病棟における死亡退院患者を対象としたデスカン ファレンス開催の要否に対する関連要因の検討. Palliative Care Research 2017; 12: 929-35.

7）クラウス・クリッペンドルフ。メッセージ分析の技法 「内容分析」への招待. 勁草書房, 東京, 1989.

8) Walsh D, Donnelly S, Rybicki L. The symptoms of advanced cancer: relationship to age, gender, and performance status in 1,000 patients. Support Care Cancer 2000; 8: 175-9.

9) Seow H, Barbera L, Sutradhar R, et al. Trajectory of performance status and symptom scores for patients with cancer during the last six months of life. J Clin Oncol 2011; 29: 1151-8.

10）杉浦正和. 役割理論の諸概念と職場におけるロール・コ ンピテンシー。早稲田国際経営研究 2013; 44: 15-29.

11) Leung J, Rioseco P, Munro P. Stress, satisfaction and burnout amongst Australian and New Zealand radiation oncologists. J Med Imaging Radiat Oncol 2015; 59: 115-24.

12) Shanafelt TD, Gradishar WJ, Kosty M, et al. Burnout and career satisfaction among US oncologists. J Clin Oncol 2014; 32: $678-86$

13) Shanafelt T, Dyrbye L. Oncologist burnout: causes, consequences, and responses. J Clin Oncol 2012; 30: 1235-41.

14) Alacacioglu A, Yavuzsen T, Dirioz M, et al. Burnout in nurses and physicians working at an oncology department. Psychooncology 2009; 18: 543-8.

15) Granek L, Ariad S, Nakash O, et al. Mixed-methods study of the impact of chronic patient death on oncologists' personal and professional lives. J Oncol Pract 2017; 13: e1-e10. 


\title{
Clinical Practice Report
}

\section{A Content Analysis of Death Conferences for Patients Who Died in a Palliative Care Unit of Cancer Specialist Hospital}

\author{
Jun Kako, ${ }^{1)}$ Yasufumi Oosono, ${ }^{2)}$ Masamitsu Kobayashi, ${ }^{1)}$ and Asuko Sekimoto ${ }^{1)}$ \\ 1) Division of Nursing, National Cancer Center Hospital East, \\ 2) Community Health Nursing, Ministry of Defense National Defense Medical College
}

\begin{abstract}
Objectives: To clarify the content of death conferences. Methods: 60 death conferences held in the palliative care unit of the National Cancer Center Hospital East between May 2012 and November 2014 were analyzed in a retrospective study. Medical records and notes from the time of the meeting were used. Results: 170 units of data were abstracted from the death conferences held during the studied period. These data were categorized into five groups: 1. supporting family members as subjects of care, 2. understanding and cherishing patient's thoughts, 3. reducing symptoms and relieving pain, 4. realizing the importance of communication between medical personnel, and 5. becoming anxious due to interaction with patients. Conclusion: The results suggest that the death conference is a useful opportunity to look back on support from various perspectives and directions.
\end{abstract}

Palliat Care Res 2018; 13(1): 115-20

Key words: oncology nursing, hospices, nurses, palliative care, terminal care 